UDC 635.78-116.424

Original research paper

doi:10.5937/AASer1845077R

Acta Agriculturae Serbica, Vol. XXIII, 45 (2018); 77-84

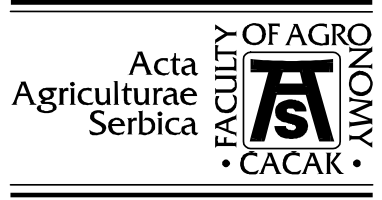

\title{
The influence of variety and fertilization on yield and content of vitamin $c$ in the root of parsley (Petroselinum ssp.)
}

\author{
Alma Rahimić ${ }^{1}$, Vedrana Komlen ${ }^{2}$, Aleksandra Govedarica-Lučić ${ }^{2}$, \\ Aleksandra Šupljeglav Jukić ${ }^{1}$ \\ ${ }^{1}$ Džemal Bijedić University of Mostar, Agromediterranean Faculty, \\ Univerzitetski kampus, 88 104, Mostar, B\&H; \\ ${ }^{2}$ University of East Sarajevo, Faculty of Agriculture, Vuka Karadžića 30, Novo \\ Istočno Sarajevo, 71 123, B\&H
}

Corresponding author: alma.rahimic@unmo.ba

\begin{abstract}
The two-year research investigated the impact of different varieties and fertilizers on the root yield and the vitamin C content in the root of parsley. Three varieties of parsley were used and three fertilization treatments were applied (mineral, organic and organomineral fertilizer) as well as control. The varieties used in the research were: 'Domestic Sawmills', 'Mooskrause', 'Berlin Semi-Long'، The root yield and the vitamin $C$ content in the root of parsley were significantly influenced by variety and type of fertilizer. With use of organic fertilizer, the highest yield of roots was achieved in both research years. The lowest vitamin $\mathrm{C}$ content was found in the unfertilized control, while the highest vitamin $\mathrm{C}$ content was obtained in the organomineral fertilizer treatment, but did not differ significantly from the treatment with organic fertilizer .
\end{abstract}

Keywords: parsley, yield, vitamin C, variety, fertilization. 


\section{Introduction}

Parsley (Petroselinum hortense) is a biennial plant that belongs to the family Apiaceae. It is grown for its turnip root and leaves of characteristic, pleasant smell and taste. Both fresh and dried parsleys are used in food, cosmetic and pharmaceutical industries, as well as for the production of spices, essential oils and medications (Lopez et al., 1999). Productivity and quality of parsley require the selection of proper genotypes for certain production conditions.

There are three types of parsley: flat-leaf parsley (ssp. neapolitanum); curlyleaf parsley (ssp. crispum), which are planted for their leaves, and turnip-rooted parsley (ssp. tuberosum), which is planted for its root. They differ in morphology and chemical content, as well as in the content of essential oils (Petropoulus et al., 2004).

Turnip-rooted parsley forms a higher and better quality root system than the other two types of parsley.

Apart from genetic properties, other factors, particularly fertilization, may influence the yield and quality of parsley.

Parsley needs a lot of supplemental nutrients for root and leaf growth and development, but excessive fertilizers, especially nitrogen can badly damage human health (Mansuroglu et al., 2011).

In general, parsley herb belongs to sources with the highest content of vitamin C in vegetables (Valšikovska et al., 2016). Parsley has a higher vitamin $\mathrm{C}$ content than lemon and orange $-100 \mathrm{~g}$ of fresh parsley leaves contain 96.88 to $312.7 \mathrm{mg}$ of vitamin $\mathrm{C}$, while the content in frozen parsley leaves ranges from 10.06 to $47.10 \mathrm{mg} / 100 \mathrm{~g}$ (Osinska et al., 2012). The same authors found vitamin $\mathrm{C}$ in trace amounts in dry parsley leaves.

As reported by Cauni et al. (2010), leafy parsley contains significantly more vitamin C (133.0 mg/100 g) compared with some other leafy vegetables (celery $85.0 \mathrm{mg} / 100 \mathrm{~g}$, lettuce $24.0 \mathrm{mg} / 100 \mathrm{~g}$, cabbage $51.0 \mathrm{mg} / 100 \mathrm{~g}$ ).

Vitamin $\mathrm{C}$ content in vegetable fruits can be influenced by many factors: genetic characteristics, climatic conditions, cultural practices, maturity, method of harvesting and storage. Higher light intensity during the growing season increases the content of vitamin $\mathrm{C}$ in the plant tissue. Excessive nitrogen fertilization reduces the vitamin $\mathrm{C}$ content. The content of vitamin $\mathrm{C}$ in many vegetable crops can be increased by decreasing irrigation because over-moisture contributes to reducing the vitamin C content (Lee et al., 2000).

The aim of the research was to determine the effect of variety and type of fertilizer on yield and vitamin $\mathrm{C}$ content in the leaf of parsley. 


\section{Materials and Methods}

The yield and vitamin $\mathrm{C}$ content in parsley root were evaluated during two growing seasons: 2013 and 2014. A two factorial field experiment was conducted in Bijelo Polje, the north suburb of Mostar. The experiment was laid out in a randomized block design with 4 replications. Plot size was $1 \mathrm{~m}^{2}$.

Three varieties of parsley were used:

- 'Domestic Sawmills'(A) - sawmill type ( $P$. hortense ssp. neapolitanum),

- 'Berlin Semi-Long' (B) - root type ( $P$. hortense ssp. Tuberosum),

- $\quad$ 'Mooskrause' (C) - curly-leaf type (P. hortense ssp.crispum).

There were three fertilization treatments in the experiment:

1. Control,

2. Organic,

3. Organomineral,

4. Mineral.

In mineral fertilization treatment, a permanently complex fertilizer NPK 8:16:24 was applied as a starter fertilizer at a rate of $720 \mathrm{~kg} / \mathrm{ha}$ and CAN $(27 \%$ $\mathrm{N}$ ) fertilizer was used in the amount of $170 \mathrm{~kg} / \mathrm{ha}$ to supplement the required quantity of N. For organic fertilization, sheep manure was used in basic fertilization at $20 \mathrm{t} / \mathrm{ha}$. Organomineral fertilizer was also applied in basic fertilization in the amount recommended for vegetable crops of $1 \mathrm{t} / \mathrm{ha}$. The organomineral fertilizer used was Phenix fertilizer, a combination of organic and mineral fertilizers whose NPK values are 6: 8: $15+\mathrm{MgO}$.

Sowing was performed in the first ten-day period of March. Seeds were sown in rows at a spacing of $20 \mathrm{~cm}$ and the rate of sowing was $3 \mathrm{~g} / \mathrm{m}^{2}$.

Before setting up the experiments, soil samples were taken from 0-30 cm depth for chemical analysis.

According to the results of soil analysis, the $\mathrm{pH}$ of the soil determined in water was slightly alkaline (7.56) and that in $\mathrm{KCl}$ was poorly acidic to neutral (6.76). The total $\mathrm{N}$ content of $0.21 \%$ indicates that the soil was well-supplied with nitrogen. As regards the content of available $\mathrm{P}_{2} \mathrm{O}_{5}(8.20 \mathrm{mg} / 100 \mathrm{~g})$, the soil sample was poorly supplied with phosphorus (3rd class). $\mathrm{K}_{2} \mathrm{O}$ content was 16.80 $\mathrm{mg} / 100 \mathrm{~g}$, which indicated a good supply $\left(2^{\text {nd }}\right.$ class $)$. The content of humus was low $-1.60 \%$.

The yield of the root ( $\mathrm{t} / \mathrm{ha}$ ) was determined by measuring the root after harvest, in the last ten days of October.

Samples for the analysis of plant material were taken after root harvest and frozen for one month. The content of vitamin $\mathrm{C}$ was determined by titration using iodide solution (iodometric method).

A two-factorial analysis of variance was used for data processing, and the significant difference between means was calculated by the LSD test. 


\section{Results and discussion}

As expected, the highest root yield values, in both research years, were obtained in the variety 'Berlin Semi-Long', and the values were statistically very high when compared with the values of the other two varieties. The lowest root yield was obtained in 'Mooskrause' in both years.

The use of organic fertilizer had many beneficial effects on growth, development and yield of parsley root, taking into consideration that in both years the highest yield was achieved under organic fertilizer. The same effect of organic fertilizer was also found by Ahmed et al. (2014). In their research, organic fertilizer (manure) had a positive influence in increasing growth and yield of carrot root. As opposed to the present results, Mader et al. (1993) reported a $25 \%$ decrease in fruit yield under organic fertilizer i.e. manure treatment, compared with conventionally grown vegetables.

Table 1 . The influence of variety and fertilization on yield of parsley root $\left(\mathrm{t} \mathrm{ha}^{-1}\right)$

\begin{tabular}{|c|c|c|c|c|c|}
\hline Year & Fertilizer & \multicolumn{3}{|c|}{ Variety } & Average \\
\hline \multirow{6}{*}{2013} & & A & $\mathrm{B}$ & $\mathrm{C}$ & \\
\hline & 1 & 51.20 & 93.32 & 29.61 & $58.04^{b}$ \\
\hline & 2 & 66.92 & 106.19 & 46.64 & $73.25^{\mathrm{a}}$ \\
\hline & 3 & 39.47 & 80.11 & 28.19 & $49.26^{\mathrm{c}}$ \\
\hline & 4 & 56.00 & 90.41 & 39.29 & $61.90^{b}$ \\
\hline & Average & $53.40^{\mathrm{b}}$ & $92.51^{\mathrm{a}}$ & $35.93^{\mathrm{c}}$ & \\
\hline & & \multicolumn{2}{|c|}{ Fertilizer } & \multicolumn{2}{|c|}{ Variety } \\
\hline \multicolumn{2}{|c|}{$\mathrm{LSD}_{0,05}$} & \multicolumn{2}{|c|}{6.17} & \multicolumn{2}{|c|}{7.14} \\
\hline \multicolumn{2}{|c|}{$\mathrm{LSD}_{0,01}$} & \multicolumn{2}{|c|}{8.4} & \multicolumn{2}{|c|}{9.73} \\
\hline \multirow{5}{*}{2014} & 1 & 17.33 & 23.75 & 9.64 & $16.91^{b}$ \\
\hline & 2 & 21.25 & 50.56 & 7.64 & $26.48^{\mathrm{a}}$ \\
\hline & 3 & 20.56 & 30.64 & 8.11 & $19.77^{b}$ \\
\hline & 4 & 26.71 & 35.83 & 10.04 & $24.19^{\mathrm{a}}$ \\
\hline & Average & $21.46^{\mathrm{b}}$ & $35.19^{\mathrm{a}}$ & $8.86^{\mathrm{c}}$ & \\
\hline & & \multicolumn{2}{|c|}{ Fertilizer } & \multicolumn{2}{|c|}{ Variety } \\
\hline \multicolumn{2}{|c|}{$\mathrm{LSD}_{0,05}$} & \multicolumn{2}{|c|}{3.12} & \multicolumn{2}{|c|}{3.6} \\
\hline \multicolumn{2}{|c|}{$\mathrm{LSD}_{0,01}$} & \multicolumn{2}{|c|}{4.26} & \multicolumn{2}{|c|}{4.91} \\
\hline \multirow{5}{*}{$\begin{array}{l}\text { Two-year } \\
\text { average }\end{array}$} & 1 & 34.26 & 58.53 & 19.62 & 37.47 \\
\hline & 2 & 44.10 & 78.37 & 27.14 & 49.87 \\
\hline & 3 & 29.96 & 55.37 & 18.15 & 34.49 \\
\hline & 4 & 41.35 & 63.12 & 24.66 & 43.04 \\
\hline & Average & 37.42 & 63.85 & 22.39 & \\
\hline
\end{tabular}


In 2013, root yield in organic treatment was statistically higher than in the control and the other two fertilization treatments. In 2014, root yield under organic treatmentwas not different from mineral treatment, while it was much higher than in the control and organic-mineral treatment. The lowest yield was obtained in 2013 under organic-mineral treatment, while the control had the lowest yield in 2014. The comparison of root yield between the two experimental years shows large differences. Depending on variety and fertilizer, root yield ranged from 28.19 to $106.19 \mathrm{t} \mathrm{ha}^{-1}$ in 2013 , and from 7.64 to $50.56 \mathrm{t} \mathrm{ha}^{-1}$ in 2014 . The strongest influence of weather conditions was noticed in beet root yield (Szopinska and Gaweda, 2013), which was significantly different across years of research.

The content of vitamin C in parsley root in 2013 was highest in 'Domestic Sawmills', and was statistically much higher than in 'Berlin Semi-Long', which had the lowest vitamin C content when compared with 'Mooskrause'. The highest level of vitamin C in 2014 was determined in 'Berlin Semi-Long', and it was significantly greater than in 'Mooskrause', but the differences were not significant when the two varieties are compared with 'Domestic Sawmills'.

Table 2. The influence of variety and fertilization on the vitamin $\mathrm{C}$ content in the root of parsley $(\mathrm{mg} / 100 \mathrm{~g})$

\begin{tabular}{|c|c|c|c|c|c|}
\hline Year & Fertilizer & \multicolumn{3}{|c|}{ Variety } & Average \\
\hline \multirow{6}{*}{2013} & & A & B & $\mathrm{C}$ & \\
\hline & 1 & 18.33 & 21.67 & 23.33 & $21.11^{\mathrm{c}}$ \\
\hline & 2 & 23.33 & 21.67 & 36.67 & $27.22^{\mathrm{ab}}$ \\
\hline & 3 & 33.33 & 26.66 & 25.00 & $28.33^{\mathrm{a}}$ \\
\hline & 4 & 25.00 & 23.33 & 18.33 & $22.22^{\mathrm{bc}}$ \\
\hline & Average & $33.16^{\mathrm{a}}$ & $23.33^{\mathrm{b}}$ & $25.83^{b}$ & \\
\hline & & \multicolumn{2}{|c|}{ Fertilizer } & \multicolumn{2}{|c|}{ Variety } \\
\hline \multicolumn{2}{|c|}{$\mathrm{LSD}_{0,05}$} & \multicolumn{2}{|c|}{5.67} & \multicolumn{2}{|c|}{6.54} \\
\hline \multicolumn{2}{|c|}{$\mathrm{LSD}_{0,01}$} & \multicolumn{2}{|c|}{7.73} & \multicolumn{2}{|c|}{8.91} \\
\hline \multirow{5}{*}{2014} & 1 & 18.33 & 23.33 & 16.67 & $19.44^{\mathrm{c}}$ \\
\hline & 2 & 32.33 & 36.67 & 33.33 & $34.11^{\mathrm{a}}$ \\
\hline & 3 & 31.67 & 38.33 & 35.00 & $35.00^{\mathrm{a}}$ \\
\hline & 4 & 28.33 & 32.33 & 20.00 & $26.89^{b}$ \\
\hline & Average & $27.66^{\mathrm{ab}}$ & $32.66^{\mathrm{a}}$ & $26.25^{\mathrm{b}}$ & \\
\hline & & \multicolumn{2}{|c|}{ Fertilizer } & \multicolumn{2}{|c|}{ Variety } \\
\hline \multicolumn{2}{|c|}{$\mathrm{LSD}_{0,05}$} & \multicolumn{2}{|c|}{4,94} & \multicolumn{2}{|c|}{5.71} \\
\hline \multicolumn{2}{|c|}{$\mathrm{LSD}_{0,01}$} & \multicolumn{2}{|c|}{6,74} & \multicolumn{2}{|c|}{7.78} \\
\hline \multirow{5}{*}{$\begin{array}{c}\text { Two- } \\
\text { year } \\
\text { average }\end{array}$} & 1 & 18.33 & 22.50 & 20.00 & 20.28 \\
\hline & 2 & 27.83 & 29.17 & 35.00 & 30.67 \\
\hline & 3 & 32.50 & 32.50 & 30.00 & 31.67 \\
\hline & 4 & 26.66 & 27.83 & 19.16 & 24.55 \\
\hline & Average & 26.33 & 28.00 & 26.04 & \\
\hline
\end{tabular}


The content of vitamin $\mathrm{C}$ in the root of parsley in both years of the present research was the highest in organic-mineral treatment, followed by organic fertilization treatment. In 2014, that content was significantly higher than in the control and mineral fertilization treatment. In 2013, these two treatments had significantly higher contents of vitamin $\mathrm{C}$ compared with the control. Umuhoza et al. (2014) reported a positive effect of organic fertilizer (manure) in increasing the content of vitamin $\mathrm{C}$ in carrot root. Increased rates of nitrogen fertilizer and increased availability of nitrogen can result in lower contents of vitamin $\mathrm{C}$ in the fruits (Lee et al. 2000).

The results of other studies on the influence of different fertilizers on the content of vitamin $\mathrm{C}$ in fruits are different. Lower levels of vitamin $\mathrm{C}$ under organic fertilizer treatment when compared with mineral fertilizer treatment were obtained by Sikora et al. (2010), while Worthington (2001) found that the content of vitamin $\mathrm{C}$ was approximately higher by $27 \%$ than in the fruit fertilized with organic fertilizer, when compared with mineral fertilizer, except in carrot cultivation. On the other hand, as determined by Fjelkner-Modig et al. (2000), the contents of vitamin C in cabbage, onion, bean and tomato were not significantly different between fertilization treatments (organic and mineral). Hunter (2011) reported increased contents of vitamin $\mathrm{C}$ in the organic cultivation of carrots and potatoes.

\section{Conclusion}

A significantly higher yield of root was produced by 'Berlin Semi-Long' than under the other treatments in both years of the research. Organic fertilizer caused the highest yield of root in both years. All three varieties of parsley had significantly higher root yields in 2013 than in 2014. The content of vitamin C in the root of parsley was dependent on the fertilizer used in both years of the research, and it was highest in the organic-mineral treatment, followed by organic fertilization treatment.

\section{References}

Ahmed A., Sambo B. E., Arunah U. L., Odion E. C. (2014): Response of Farmyard Manure and Inorganic Fertilizers for Sustainable Growth of Carrot (Daucus carota L.) in Northern Nigeria. IOSR Journal of Agriculture and Veterinary Science, vol. 7, Issue 2 Ver. II: 18-25.

Fjelkner-Modig S., Bengtsson H., Stegmark R., Nyström S. (2000): The influence of organic and integrated production on nutritional, sensory and agricultural aspects of 
vegetable raw materials for food production. Acta Agric. Scand., Sect B, Soil Plant Science, 50: 102-113.

Hunter D., Foster M., McArthur J. O., Ojha R., Petocz P., Samman S. (2011): Evaluation of the micronutrient composition of plant foods produced by organic and conventional agricultural methods. Critical Reviews in Food Science and Nutrition, 51: 571-582.

Lee S.K., Kader A.A. (2000): Preharvest and postharvest factors influencing vitamin C content of horticultural crops. Postharvest Biology and Technology, 20: 207-220.

Lopez M., Shancez - Mendoza I., Ochoa-Alejo N. (1999): Coparative study of volatile components and fatty acids of plants and in vitro cultures of parsley (Petroselinum cripsum Mill). Journal of Agricultural and Food Chemestry, 47 (8): 3292-3296.

Mader P., Pfiffner L., Niggli U., Balzer U., Balzer F., Besson J-M., Plochberger Velimirov A., Boltzmann L. (1993): Effect of three farming systems (bio-dynamic, bio-organic, conventional) on yield and quality of beetroot (Beta vulgaris L. var. esculenta L.) in a seven year crop rotation. Acta Horticultrae, 339: 11-31.

Mansuroglu, S. G., Bozkurt S., Telli S., Uygur V. (2011): Nitrate, Nitrite and Chlorophyll Contents of Parsley Irrigated with Different Water Levels of Mini Sprinkler Irrigation under Different Amounts of Nitrogen Fertilizers. Journal of Cell and Plant Sciences, 2 (3): 1-8.

Osinska E., Roslon W., Drzewiecka M. (2012): The evaluation of quality of selected cultivars of parsley (Petroselinum sativum L.ssp. crispum). Acta Scientiarum Polonorum Horticulture, 11 (4): 47-57.

Petropoulos S., Daferera D., Akoumianakis C., Passam H., Polissiou M. (2004): The effect of sowing date and growth stage on the essential oil composition of three types of parsley (Petroselinum crispum). Journal of the Science of Food and Agriculture, 84: 1606-1610.

Sikora M., Klonowska K., Hallmann E., Rembialkowska E. (2010): Nutritive quality of red beet roots from organic and conventional production. In: Rembialkowska E. (ed.), The impact of organic production methods on the vegetable product quality. Published by SGGW, Warszawa, Poland: 209-220.

Szopinska A.A., Gaweda M. (2013): Comparison of yield and quality of red beet roots cultivated using conventional, integrated and organic method. Journal of Horticultural Research, vol. 21 (1): 107-114.

Umuhoza J.N.K., Sylvestre H., Philippe S. (2014): Nutritional quality of carrot (Daucus carota L.) as influenced by farm yard manure. World Journal of Agricultural Sciences, vol. 2 (5): 102-107.

Valšikova M., Mezeyova, I., Rehuš M., Šlosar M. (2016): Changes Of Vitamin C Content In Celery And Parsley Herb After Processing. Potravinarstvo, 10 (1): 637642.

Worthington V. (2001): Nutritional quality of organic versus conventional fruits, vegetables, and grains. Journal of Alternative Complement Medicine, 7 (2): 161-173. 


\title{
UTICAJ SORTE I GNOJIDBE NA PRINOS I SADRŽAJ VITAMINA C U KORIJENU PERŠUNA (Petroselinum ssp.)
}

\author{
Alma Rahimić ${ }^{1}$, Vedrana Komlen ${ }^{1}$, Aleksandra Govedarica-Lučić ${ }^{2}$, Aleksandra \\ Šupljeglav Jukić ${ }^{1}$ \\ ${ }^{1}$ Univerzitet Džemal Bijedić u Mostaru, Agromediteranski fakultet, \\ Univerzitetski kampus, 88 104, Mostar, B\&H; \\ ${ }^{2}$ Univerzitet u Istočnom Sarajevu, Poljoprivredni fakultet, Vuka Karadžića 30, \\ Novo Istočno Sarajevo, 71 123, B\&H
}

\section{Rezime}

U dvogodišnjem istraživanju ispitan je uticaj različitih sorti i gnojiva na prinos korijena i sadržaj vitamina $\mathrm{C}$ u korijenu peršuna. $\mathrm{U}$ istraživanju su korištene tri sorte peršuna i primjenjene tri varijante gnojidbe (mineralna, organska i organomineralna) i kontrolna varijanta. Korištene sorte $\mathrm{u}$ istraživanju su: „Domaći lišćar“", „Mooskrause“ i „Berlinski poludugi“. Na visinu prinosa korijena i sadržaj vitamina $\mathrm{C}$ u korijenu peršuna značajno su uticali sorta i vrsta gnojiva. Primjenom organskog gnojiva postignut je najveći prinos korijena u obje godine istraživanja. Najmanji sadržaj vitamina $\mathrm{C}$ utvrđen je u varijanti bez primjene gnojiva (kontrola), dok je najveći sadržaj vitamina $\mathrm{C}$ bio $\mathrm{u}$ organomineralnoj varijanti, ali se nije značajno razlikovao od organske varijante gnojidbe.

Ključne reči: peršun, prinos, vitamin C, sorta, gnojidba. 